\title{
RELATIONSHIP BETWEEN CREDIT DEFAULT SWAPS, DIRECT FOREIGN INVESTMENTS AND PORTFOLIO INVESTMENTS: TIME SERIES ANALYSIS FOR TURKEY
}

\section{Dr. Ahmet KAHILOGULLARI}

Çanakkale Onsekiz Mart University, Republic of Turkey, ahmetkahil@gmail.com

\section{Article info}

\section{Article history:}

Accepted 13 Nevember 2018

Available online 31 December 2018

\section{Keywords:}

Credit Default Swap, Foreign Direct Investments, Portfolio Investments, Time Series Analysis, ARDL Method

* "This article derived from doctoral thesis that name is "Relationship Between Credit Default Swaps, Direct F oreign Investments and Portfolio Investments: Time Series Analysis for Turkey"

\begin{abstract}
A b s t r a c t
Foreign investors who come to the country receive credit default swaps which are an insurance against the possibility of failing to fulfil the obligations of the host country. The purpose of using this financial instrument is to provide protection against possible default situations. The higher the value of the credit default swap premium, it means that the risk of default is relatively high whereas the lower risk means that the default risk is relatively low. The purpose of this study is to analyse with ARDL (Autoregressive Distributed Lag Model) Method Turkey's credit default swap premium for January 2005-September 2017 period and the long run and short run relationship between foreign direct investment and portfolio investments in Turkey. According to the results of the study, there is no long run and short run relationship between credit default swaps and foreign direct investments in Turkey; The presence of a long run and short run relationship with portfolio investments has been identified.
\end{abstract}

\section{Introduction}

One of the most important aims of providing capital accumulation and economic development in capitalist countries is foreign direct investments. Via foreign capital investments, countries, accelerating capital accumulation processes, try to solve their economic problems such as economic constriction, unemployment, and foreign deficit but partly. Foreign investments actualize as direct investments, portfolio investments and other investments. Among the sorts of these foreign investments, the effect of direct investments on real sector is more due to the fact that they are related to real sector itself. compared to the other sorts of foreign investment.

Importance of foreign direct investments in terms of country economies engenders the problem with being able to attract these investments to the country. The foreigners who will make investment will inherently prefer the countries, in which first of all, there is no uncertainties, and there is profitability. This preference accompanies the problem with measuring risk.

As a result of developments in financial system, "credit rating" is referred as a criterion of becoming investible in the countries and whether or not the countries will meet their financial liabilities. With advanced analysis techniques used, the grades varying from 1 to 6 are given by credit ratings agencies such as Standard Poor's, Moody's and Fitch to the countries according to the varying quality degrees and each quality degree gives information about economic appearance of the countries in such a way that each quality degree can be reduced to letter grades varying from AAA to D. This grading of interest is also made for the companies and municipalities as well as countries.

The grading mentioned indicates default probability in the interval of very high - very low. Credit Default Swaps (CDS) that 
have quality of insurance against that.the probability the agencies such as municipalities, companies, and etc. go to default are processed in over-the counter markets. According to this, the higher a CDS premium is priced in the market, the more the default risk of the support asset is more. Otherwise, i.e. in case that CDS premium is low, default risk is low. From this aspect, CDS premiums come to our face as a financial instrument processed in markets with concretized form of the grades given by credit rating agencies. In this context, it can be said that CDS premiums processed for countries is concrete data regarding whether or not investment will be made to countries. However, that credit rating is reliable and that CDS premiums are the subject of speculative processes accompany a problem in terms of those making decision for investment. This problem is the problem with the reliability of the rating made. As a matter of fact, Enron scandal in 2001, the collapses experienced in Worldcom in 2002 and Parmalat in 2003, bankruptcy of Lehman \& Brothers in 2008, and assigning high credit grades almost before those experienced makes right to question the reliability mentioned.

The problem with reliability mentioned above, in case that investment is made on the countries according to credit ratings, reveals the requirement to be examined the relationship between foreign investments and these grades.

The subject of this study is to test the relationship between CDS in Turkey and foreign capital by means of Time Series Analysis by using monthly data regarding CDS and foreign direct investments for the period of September 2017.

\section{Literature}

When the literature related to credit default swaps is regarded, it will be seen that the studies are the ones, in which the relationships between CDS premiums and liabilities, effect of social events on CDS premiums; and their effects on the indicators of financial stability such as inflation, interest rates, and CDS premiums are predominantly studied.

Norden and Weber (2004), in the study they carried out for the period of 2000-2002, obtained the conclusion that as a result of grade declarations of three credit rating agencies consisting of Standard \& Poor's, Moody's and Fitch either, the stock and CDS markets pioneered to bond markets.

Özkaplan (2011), in the study he carried out, tested the relationship of CDS premium with financial indicators such as Dow Jones Index, IMKB 100 Index, and foreign currency basket by means of Granger causality analysis for the period 2002-2010. In the study of interest, causality relationship between variables is met and it was identified that the departure point of this causality relationship were CDSs.

In the study, in which the effect of the interest rate and exchange rate is studied on CDS, VAR analysis and Granger causality test were applied. The study, in which USA for the period of March 2008-September 2010 and France for the period of August 2005 - September 2010 are considered, revealed that while country interest rates have a limited effect on CDS spreads, the effect of exchange rates on CDS was significant.

Coronado et al (2012), in a study covering the period 2007-2010 for 8 European countries, tested the relationship between CDSs representing credit risk and indices of stock markets representing market risk by means of the vector autoregression and panel data analysis methods. Analysis, in the period mentioned, revealed the conclusion that stock market played a leading role in this relationship. However, when the year 2009 are excluded from the analysis, a case, where CDSs played a key role in this relationship, was met and it was expressed that this case was more noticeable in the countries under high risk.

Castaneda and Vargas (2012), in the study they carried out for measuring how CDS premiums are affected from foreigners 'perception, studied the effect of the armed conflicts, in which the events that occurred in Colombia in 2008 such as death of Raul Reyes, release of Clara Rojas, and rescue of Ingrid Betancourt stood out. The results of the study revealed that the effect of conflicts on risk perception of foreigners was very significant.

Marzano et al (2014), in a study, where they studied the effect of CDSs in a stock market of four different countries (Europe other than United Kingdom, USA, Japan) by means of a linear economic model, revealed that the variable CDS accounted for the movements in stock prices accounted for by $71 \%$.

Koy (2014), in the study, where he studied the relationship CDS premiums and Euro-bond premiums by means of unit root test and causality analysis, dealt with 8 countries, among which there 
were Germany, France, Italy, Ireland, Greece, Portugal, Spain, and Turkey. The findings in the study were in the form of that CDS premiums of France and Italy gave direction to bond premiums.

Tuna et al (2014), in the study they carried out, tested the correlation between five-year CDS rates in terms of US Dollar in Turkey as well as 5 developing selected countries and 2 developed countries for before and after 2008 and revealed that the contagion effect of the crisis was only present between Turkey and developing countries.

A study, carried out by Cho and Rhee (2014), after 2008 global financial crisis, for Asian countries, which have the developed capital markets and among which the countries such as China, Japan, South Korea, and Singapore take place, revealed that the effect of local productivity as well as the decrease of CDS premiums after the outbreak of the crisis significantly contributed to capital inflows to the countries under consideration.

Stolbov (2014), in the study, in which he accounted for the causality relationships between CDSs continuing over debt crisis of the most important countries of Europe (Germany, France, United Kingdom, Italy, and Spain), introduced the signals of the presence of decomposition in CDS markets of both country group. Another conclusion of the study was in the way that the effect of non-European countries on CDS market was limited over debt crisis.

A study, carried out by Koziol et al. (2015), concluded that while the relevant factors for CDS prices before 2008 financial crisis, the importance of the factors under consideration increased during and after crisis period

In the study, carried out by Kim et al (2015) and in which the effect of financial crisis that began in USA in 2008 on foreign currency markets were studied for the countries consisting of Philippines, Thailand, Taiwan, Indonesia, and South Korea, GARCH models were used and it was concluded that there was a dominant effect of foreign investments on international capital markets. Another conclusion turning out from the same study was that Libor-OIS spread and country CDS as well as foreign investments were effective on foreign currency markets.
Wisniewski and Lambe (2015), in the study they carried out, studied dynamic interaction between ambiguities of economic policy and fluctuations in the costs of credit protection and concluded that CDS spreads gave significantly reaction to shocks in policy risk.

Kocsis and Monostori (2016), in a study, in which they studied the factors affecting country CDSs for 13 countries, among which there is also Turkey, concluded that local factors were more effective than global factors on CDS spreads. According to the conclusion, expressed in the study, it was emphasized that the factor of institutional power stood out as local factor.

Pereira Da Silva (2016), in a study, in which he measured the ability of CDSs giving information about risk perception to predict stock prices related to the countries, firms, and etc., obtained the conclusion that CDSs were not a good alternative for the investors having the purpose of providing short term benefit

Da Costa Filho (2017), related to Brazil, in a study, in which he studied what long term returns of inflation-dependent bonds depend on for the period of December 2005-February 2010, concluded that the main determinants of the returns of interest were ten-year CDSs and interest rates in USA.

When regarded to the literature concerning investors, it is seen that the studies are intensively on the determinants of foreign investments. Again, in the literature of interest, although the relationships between country risk and foreign investments are studied, it can be said that the studies, in which the relationships between CDS premium and foreign investments are studied, are in very limited number.

Nantal, in the study he carried out for petroleum exporting countries, he studied the relationship between country risk and foreign investments related to the period 1984-1996 and concluded that there was a negative directional relationship between country risk and foreign investments.

Bevan and Estrin (2004), in a study they tested the effect of 
country risk of transition economies of Europe on foreign direct investments for the period 1994-1998 by the method of panel data analysis, concluded that the relationship of country risk with foreign direct investments was insignificant.

Emir et al (2013), in another study, tested the relationship between foreign direct investments and country risk and macroeconomic variables in Turkey by Johansen co-integration analysis and error correction model for the period 1992-2010. According to the findings of the study, there was a unidirectional causality relationship between foreign direct investments and politics risk and country rating

Topal and Gül (2016), in their study, tested the relationship between economic risk and foreign direct investment by means of time series analysis for Turkey in respect of 2013-2014. In the study of interest, it was introduced that there was a negative directional but also significant relationship. In addition, in the study, it was obtained the conclusion that this relationship was not unidirectional, and that country risk decreased as foreign direct capital investments increased.

\section{Dataset, method and analysis}

In this study, the relationship between the variables of credit risk swap (CDS), portfolio investments (PORTFOY), and foreign direct investments (YABANCI) was studied. For this purpose, using monthly data of the period 2005:1-2017:09, first of all, summary statistics regarding the variables were given in Table 1 .

Table 1: Summary Statistics

\begin{tabular}{|l|l|l|l|}
\hline & CDS & PORTFOY & YABANCI \\
\hline Mean & 221.43 & 1100.47 & 931.60 \\
\hline Median & 207.77 & 1005.00 & 633.00 \\
\hline Biggest & 521.21 & 9061.00 & 6571.00 \\
\hline Least & 118.85 & -4791.00 & 46.00 \\
\hline $\begin{array}{l}\text { Standard } \\
\text { Deviation }\end{array}$ & 69.32 & 2264.46 & 991.90 \\
\hline Skew & 1.62 & 0.35 & 2.97 \\
\hline Kurtosis & 6.90 & 3.38 & 14.26 \\
\hline
\end{tabular}

\subsection{Methodology}

In this study, in which the relationship of default swaps with foreign direct investments and portfolio investments were examined, and as methodology, ARDL (Autoregressive Distributed Lag) method, one of principal time series analysis method, was used. In this context, first of all, stationarity structures of variables were tested by unit root tests and later, long term relationship between variables was studied. Stationarity tests mentioned are Augmented Dickey Fuller (ADF), Phillips Perron (PP) and Zivot-Andrews (ZA) tests.

In order to be able to reach the presence of significant relationships between the variables included in the analysis, it is necessary for the series used to be stationary

Augmented Dickey Fuller test used in unit root analysis indicates whether or not the variables will be formed by an autoregressive process (AR). The main assumptions of this test is that error terms are accepted in randomly proceeding and are co- variance (Kurt 2016: 83-84).

Table 2: Results of ADF Test

\begin{tabular}{|c|c|c|c|c|}
\hline & & & $\begin{array}{l}\mathrm{t}- \\
\text { statistics }\end{array}$ & p-value \\
\hline CDS & Level & $\begin{array}{l}\text { Without Constant } \\
\text { and Without Trend }\end{array}$ & $\begin{array}{l}- \\
1.034985\end{array}$ & 0.2699 \\
\hline CDS & Level & With Constant & $\begin{array}{l}- \\
2.901366\end{array}$ & 0.0475 \\
\hline CDS & Level & $\begin{array}{l}\text { With Constant and } \\
\text { With trend }\end{array}$ & $\begin{array}{l}- \\
2.893343\end{array}$ & 0.1676 \\
\hline CDS & $\begin{array}{l}\text { The First } \\
\text { Difference }\end{array}$ & $\begin{array}{l}\text { Without Constant } \\
\text { and Without Trend }\end{array}$ & $\begin{array}{l}- \\
10.36369\end{array}$ & 0.0000 \\
\hline CDS & $\begin{array}{l}\text { The First } \\
\text { Difference }\end{array}$ & With Constant & $\begin{array}{l}- \\
10.33081\end{array}$ & 0.0000 \\
\hline CDS & $\begin{array}{l}\text { The First } \\
\text { Difference }\end{array}$ & $\begin{array}{l}\text { With constant and } \\
\text { trend }\end{array}$ & $\begin{array}{l}- \\
10.29768\end{array}$ & 0.0000 \\
\hline YABANCI & Level & $\begin{array}{l}\text { Without Constant } \\
\text { and Without Trend }\end{array}$ & $\begin{array}{l}- \\
1.499915\end{array}$ & 0.1248 \\
\hline YABANCI & Level & With Constant & $\begin{array}{l}- \\
3.606503\end{array}$ & 0.0067 \\
\hline YABANCI & Level & $\begin{array}{l}\text { With Constant and } \\
\text { With Trend }\end{array}$ & $\begin{array}{l}- \\
4.146073\end{array}$ & 0.0068 \\
\hline YABANCI & $\begin{array}{l}\text { The First } \\
\text { Difference }\end{array}$ & $\begin{array}{l}\text { Without Constant } \\
\text { and Without Trend }\end{array}$ & $\begin{array}{l}- \\
12.99691\end{array}$ & 0.0000 \\
\hline YABANCI & $\begin{array}{l}\text { The First } \\
\text { Difference }\end{array}$ & With Constant & $\begin{array}{l}- \\
12.95210\end{array}$ & 0.0000 \\
\hline YABANCI & The First & With Constant and & - & 0.0000 \\
\hline
\end{tabular}




\begin{tabular}{|c|c|c|c|c|}
\hline & Difference & With Trend & .12 .94615 & \\
\hline PORTFOY & Level & $\begin{array}{l}\text { Without Trend and } \\
\text { Without Trend }\end{array}$ & $\begin{array}{l}- \\
7.733159\end{array}$ & 0.0000 \\
\hline PORTFOY & Level & With Constant & $\begin{array}{l}- \\
8.957314\end{array}$ & 0.0000 \\
\hline PORTFOY & Level & $\begin{array}{l}\text { With Constant and } \\
\text { Trend }\end{array}$ & $\begin{array}{l}- \\
9.024088\end{array}$ & 0.0000 \\
\hline PORTFOY & $\begin{array}{l}\text { The First } \\
\text { Difference }\end{array}$ & $\begin{array}{l}\text { Without Constant } \\
\text { and Without Trend }\end{array}$ & $\begin{array}{l}- \\
10.05454\end{array}$ & 0.0000 \\
\hline PORTFOY & $\begin{array}{l}\text { The First } \\
\text { Difference }\end{array}$ & With Constant & $\begin{array}{l}- \\
10.02246\end{array}$ & 0.0000 \\
\hline PORTFOY & $\begin{array}{l}\text { The First } \\
\text { Difference }\end{array}$ & $\begin{array}{l}\text { With Constant and } \\
\text { With Trend }\end{array}$ & -9.98952 & 0.0000 \\
\hline
\end{tabular}

In Table 2, the results of ADF are given in both at the level and taking its first difference for "without constant and without trend" and "with constant and with trends" models. According to this, test statistics for the model that is "without constant and without trend at the level" for the variable CDS was predicted as 1.034985 and probability value as 0.2699 .

Hence, regarding this variable, "null hypothesis" $\mathbf{H}_{0}$ : There is unit root" was not rejected at the confidence level of $90 \%$ and it was concluded that the variable CDS was not stationary at the level in the context of "without constant and without trend" model i.e. that there was unit root. Beside this, it is seen that the variable CDS is stationary for the model that is "with constant at the level" with the probability value of 0.0475 at the significance level of $90 \%$, while it is not stationary for the model that is "with constant and with trend"

For the variable YABANCI, when regarded to the model that is "without constant and without trend, with constant and trend", it can be seen that the probability values are 0.1248; 0.0067 and 0.0068 in order. When regarded to these probability values, for the variable of interest, it was concluded that it was not stationary in the model that is "without constant- without trend" and in the model that is "with constant -with trend", it was stationary with the confidence of $99 \%$.

On the other hand, when regarded to the variable PORTFOY, the probability values obtained for three models established at the level can be seen by regarding in the model that is "without constant -without trend and with constant-with trend", respectively. For this variable, since probability values in all models are " $0.0000 "$ ", it can be said that the variable is also stationary at the level in three models.

In summary, according to ADF test results, it can be said that the variables CDS and YABANCI are stationary or not at the level in such a way that it will vary according to "with constant, without constant -without trend, and with constant -trend" models, while the variable "PORTFOY" is (0) that is stationary at the level. Beside this, when the first differences of three series were taken, it was concluded that they were first degree I(1) stationary in every three models.

In the study, after ADF test was made, in order to study whether or not there was unit root, unit root test (PP) developed by Philips and Perron (1988) was made. In PP test, as critical value, critical values used in ADF test were used. In this test, similar to ADF test, "without constant and without trend, with constant, with constant and with trend" models were made both for the level of series and by taking their first differences. Test results are shown in Table 3.

Table 3: The results of PP Unit Root Test

\begin{tabular}{|c|c|c|c|c|}
\hline & & & t-statistics & $p$-value \\
\hline CDS & Level & $\begin{array}{l}\text { Without Constant and } \\
\text { Without Trend }\end{array}$ & -1.058782 & 0.2608 \\
\hline CDS & Level & With Constant & -3.244475 & 0.0194 \\
\hline CDS & Level & $\begin{array}{l}\text { With Constant and } \\
\text { With Trend }\end{array}$ & -3.238749 & 0.0809 \\
\hline CDS & \begin{tabular}{|l|} 
First \\
Difference
\end{tabular} & $\begin{array}{l}\text { Without Constant and } \\
\text { Without Trend }\end{array}$ & -10.93298 & 0.0000 \\
\hline CDS & \begin{tabular}{|l|} 
First \\
Difference
\end{tabular} & With Constant & -10.89569 & 0.0000 \\
\hline CDS & \begin{tabular}{|l|} 
First \\
Difference
\end{tabular} & $\begin{array}{l}\text { With Constant and } \\
\text { With Trend }\end{array}$ & -10.85850 & 0.0000 \\
\hline YABANCI & Level & $\begin{array}{l}\text { Without Constant and } \\
\text { Without Trend }\end{array}$ & -8.400058 & 0.0000 \\
\hline YABANCI & Level & With Constant & -12.04255 & 0.0000 \\
\hline YABANCI & Level & $\begin{array}{l}\text { With Constant and } \\
\text { With Trend }\end{array}$ & -12.30733 & 0.0000 \\
\hline YABANCI & \begin{tabular}{|l|} 
First \\
Difference
\end{tabular} & $\begin{array}{l}\text { Without Constant and } \\
\text { Without Trend }\end{array}$ & \begin{tabular}{l|l}
-55.69009 \\
\end{tabular} & 0.0000 \\
\hline YABANCI & \begin{tabular}{|l|} 
First \\
Difference
\end{tabular} & With Constant & -55.43571 & 0.0001 \\
\hline YABANCI & \begin{tabular}{|l|} 
First \\
Difference
\end{tabular} & $\begin{array}{l}\text { With Constant and } \\
\text { With Trend }\end{array}$ & -56.25372 & 0.0001 \\
\hline PORTFOY & Level & $\begin{array}{l}\text { Without Constant and } \\
\text { Without Trend }\end{array}$ & -8.266226 & 0.0000 \\
\hline
\end{tabular}




\begin{tabular}{|l|l|l|l|l|}
\hline PORTFOY & Level & With Constant & -9.194053 & 0.0000 \\
\hline PORTFOY & Level & $\begin{array}{l}\text { With Constant and } \\
\text { With Trend }\end{array}$ & -9.159862 & 0.0000 \\
\hline PORTFOY & $\begin{array}{l}\text { First } \\
\text { Difference }\end{array}$ & $\begin{array}{l}\text { Without Constant and } \\
\text { Without Trend }\end{array}$ & -71.49276 & 0.0000 \\
\hline PORTFOY & $\begin{array}{l}\text { First } \\
\text { Difference }\end{array}$ & With Constant & -72.00527 & 0.0001 \\
\hline PORTFOY & $\begin{array}{l}\text { First } \\
\text { Difference }\end{array}$ & $\begin{array}{l}\text { With Constant and } \\
\text { With Trend }\end{array}$ & -72.46529 & 0.0001 \\
\hline
\end{tabular}

When regarded to PP test results shown in Table 3 are regarded, it is seen that the variable CDS has -3.244475 test statistics for "with constant" model with the value of 0.0194 at the level. Hence, in this test, it can be said that the variable CDS does not have unit root in "with constant" model. In spite of this, in "without constant and without trend" model, the variable CDS has unit root. In every three models established at the level for the variable YABANCI, probability value has been 0 (zero). According to this it can be said that the variable YABANCI is stationary at the confidence level of $99 \%$. The results for the variable POTFOY show similarity to ADF test. According to this, the variable PORTFOY is stationary at the level. In addition to these, when the first differences regarding every three variables, it is seen that the variables are stationary in three model as well.

In the models, in which the relationships between financial variables are examined, one of the issues that are necessary to pay attention is structural break. The causes such as the changes in economic policies, crises, natural disasters, and technological changes can lead to structural break. The power of unit root tests not considering these structural breaks and these tests become inconsistent. In this framework, unit root test with structural break (ZA), developed by Zivot and Andrews (1992) and based on the assumption that the date of structural break is not predicted, was used by establishing "with constant" model (Model A), "with trend" model, and "with constant and with trend" model (Model C). In the model established, taking the highest lagging number as 4 , the relevant models were predicted.

The results regarding Model A, Model B and Model C, established for the variable CDS are given place in Table 4.

Table 4: The results of ZA Test for the variable CDS

\begin{tabular}{|l|l|l|l|}
\hline Sort of Model & t-statistics & p-statistics & Break Period \\
\hline Model A & -4.235290 & 0.079886 & $2010 / 03$ \\
\hline
\end{tabular}

\begin{tabular}{|l|l|l|l|}
\hline Model B & -3.926309 & 0.622986 & $2008 / 11$ \\
\hline Model C & -5.015842 & $1.02 \mathrm{E}-0.5$ & $2009 / 04$ \\
\hline
\end{tabular}

When regarded to the results of ZA test for the variable CDS, it is seen that t-statistics is stationary with -4.235290 and that pstatistics value, with .079886 at the significance level of $90^{\wedge} \%$ for Model A. In Model B, the probability value of 0.622986 for the variable CDS shows that the variable in this model is not stationary, namely, that it has unit root. For the same variable, when regarded to Model $\mathrm{C}$, it shows the result that there is a stationary structure.

In ZA test carried out for the variable YABANCI, due to the fact that there is no full rank, Model $\mathrm{C}$ cannot be formed. In spite of this, the results of ZA test obtained for the variable YABANCI are given in Table 5, while structural breaks regarding Model A and Model B are shown in Graph 1 and 2, respectively.

Table 5: The Results of ZA Test for the Variable YABANCI

\begin{tabular}{|l|l|l|l|}
\hline Sort of Model & t-statistics & p-statistics & Break Period \\
\hline Model A & -4.619171 & 0.147813 & $2008 / 08$ \\
\hline Model B & -4.281044 & 0.666191 & $2009 / 12$ \\
\hline Model C & - & - & - \\
\hline
\end{tabular}

When regarded to the results of the test in terms of the presence of unit root, it is seen that probability value for Model A is 0.147813 and 0.666191 for Model B. In this context, it can be said that there is unit root for unit root.

The results of ZA test for the variable PORTFOY are:

Table 6: The Results of ZA Test for the Variable PORTFOY

\begin{tabular}{|l|l|l|l|}
\hline Sort of Model & t-statistics & p-statistics & Break Period \\
\hline Model A & -9.661831 & 0.000501 & $2013 / 05$ \\
\hline Model B & -9.242948 & 0.024722 & $2012 / 11$ \\
\hline Model C & -9.952066 & 0.000390 & $2015 / 02$ \\
\hline
\end{tabular}

According to the results of ZA test stated in Table 6, also in three models, in case of structural break, the null hypothesis that "there is unit root" was rejected. That is, the variable PORTFOY is stationary in every three models. 


\subsection{ARDL Model}

Since series used in this study was not integrated into the same level, co-integration analysis cannot be carried out and, in view of this, ARDL model was referred to. Another reason for referring to this model is that it is possible to be able to analyze whether or not there is a long term relationship between the variable CDS and the variables YABANCI and PORTFOY. That the model of interest enables to establish error correction model can be considered as another reason. In ARDL model, the equation of bound test is expressed as follows (Esen, Yildırım and Kostakoğlu 2012: 251-267):

$\Delta Y_{t}=\Psi_{0} \sum_{i=1}^{m} \Psi_{1 i} \Delta Y_{t-i}+\sum_{i=0}^{m} \Psi_{2 i} \Delta X_{1 t-i}+\cdots+$ $\sum_{i=0}^{m} \Psi_{k i} \Delta X_{k t-i}+\xi_{1} Y_{t-1}+\xi_{2} X_{1 t-1}+\cdots+\xi_{k} X_{k t-1}+u_{t}$.

In the equation, while $\Psi$ is a constant term, $\Delta$ expresses difference term and $\mathrm{u}$, error term. In the model under consideration, identification of suitable lagging length is important in terms of being able to question co-integration. In the model, after lagging length is identified by Akaike and Schwarz criteria, the prediction of the model under consideration can be made by Least Squares Method (LSM). In ARDL model, hypotheses related cointegration relationships are established (Kurt 2016: 85):

$H_{0}: \xi_{1}=\xi_{2}=\cdots=\xi_{k}=0 \rightarrow$ There is no co - integration .

$H_{1}: \xi_{1} \neq \xi_{2} \neq \cdots \neq \xi_{k} \neq 0 \rightarrow$ There is co - integration.

In co-integration, while hypothesis is tested, F tests are compared with asymptotic critical values. In evaluation made after determining the lower and upper limits, if F-statistics value is bigger than lower limit, hypothesis is accepted and the conclusion that there is no co-integration. If F-statistics is bigger than upper limit, $\mathrm{H}_{0}$ hypothesis is rejected and it is concluded that there is a co-integration. If $\mathrm{F}$ statistics calculated as a value between the lower and upper limits (Lower limit $>F>$ Upper Limit), there will be a case of indecisiveness and anything will not be said about the presence of co-integration. In ARDL model, long term relationships are expressed with the following equation.

$Y_{t}=\Psi_{0}+\sum_{i=1}^{m} \Psi_{1 i} \Delta Y_{t-i}+\sum_{i=0}^{n} \Psi_{2 i} \Delta X_{1 t-1}+\cdots+$ $\sum_{i=0}^{r} \Psi_{k i} \Delta X_{k t-i}+u_{t}$

After long term relationships are obtained by means of this equation, the following equation is used for obtaining short-term relationships:

$$
\begin{aligned}
& \Delta Y_{t}=\Psi_{0}+\sum_{i=1}^{m} \Psi_{1 i} \Delta Y_{t-i}+\sum_{i=0}^{n} \Psi_{2 i} \Delta X_{1 t-1}+\cdots+ \\
& \sum_{i=0}^{r} \Psi_{k i} \Delta X_{k t-i}+\mu e c m_{t-1}+u_{t}
\end{aligned}
$$

This equation is a lagged value of the remains of the equation belonging to long term relationship. After these explanations made regarding ARDL method, in the following Model 1, the findings of the variables CDS-YABANCI will be given place and, in Model 2, analysis findings of the variables CDSPORTFOY.

\subsubsection{Model 1: The relationship of foreign direct investments with CDS}

In this study, in order to identify the relationships between the variables after unit root test, for being able to be applied ARDL model, first of all, whether or not the problem with autocorrelation was studied. For Model 1, i.e. in Breusch Goldfrey test made before proceeding the test of the relationship between CDS and foreign direct investments, it was seen that there was a problem with autocorrelation in the model. The results of White test are shown in Table 7 and 8.

Table 7: Results of White Test for Model 1: Table A

\begin{tabular}{|l|l|l|l|}
\hline \multicolumn{3}{|l|}{ Heteroskedasticity Test: White } & \\
\hline F Statistics & 1.452037 & Prob. F(19,130) & 0.1141 \\
\hline Obs*R-squared & 26.26016 & Prob. Chi-Square(19) & 0.1231 \\
\hline Scaledexplained SS & 36.01852 & Prob. Chi-Square(19) & 0.0105 \\
\hline
\end{tabular}

Table 8: Results of White Test for Model 1: Table B

\begin{tabular}{|l|l|l|l|l|}
\hline & AC & PAC & Q-Stat & Prob* $^{*}$ \\
\hline 1 & -0.008 & -0.008 & 0.0094 & 0.923 \\
\hline 2 & -0.095 & -0.095 & 1.4110 & 0.494 \\
\hline 3 & -0.014 & -0.016 & 1.4410 & 0.696 \\
\hline 4 & -0.029 & -0.039 & 1.5721 & 0.814 \\
\hline
\end{tabular}




\begin{tabular}{|l|l|l|l|l|}
\hline 5 & 0.298 & 0.297 & 15.507 & 0.008 \\
\hline 6 & 0.019 & 0.017 & 15.565 & 0.016 \\
\hline 7 & -0.093 & -0.040 & 16.933 & 0.018 \\
\hline 8 & 0.054 & 0.062 & 17.400 & 0.026 \\
\hline 9 & 0.041 & 0.053 & 17.665 & 0.039 \\
\hline 10 & -0.102 & -0.199 & 19.347 & 0.036 \\
\hline 11 & 0.015 & 0.008 & 19.382 & 0.055 \\
\hline 12 & 0.029 & 0.060 & 19.525 & 0.077 \\
\hline 13 & 0.029 & -0.002 & 19.667 & 0.104 \\
\hline 14 & 0.019 & -0.024 & 19.730 & 0.139 \\
\hline 15 & -0.130 & -0.030 & 22.594 & 0.093 \\
\hline 16 & 0.020 & 0.031 & 22.661 & 0.123 \\
\hline 17 & -0.013 & -0.093 & 22.692 & 0.160 \\
\hline 18 & -0.043 & -0.046 & 23.018 & 0.190 \\
\hline 19 & 0.086 & 0.112 & 24.301 & 0.185 \\
\hline 20 & -0.079 & -0.064 & 25.395 & 0.187 \\
\hline 21 & -0.074 & -0.105 & 26.374 & 0.193 \\
\hline 22 & -0.036 & -0.010 & 26.607 & 0.227 \\
\hline 23 & -0.076 & -0.035 & 27.649 & 0.229 \\
\hline 24 & 0.105 & 0.032 & 29.652 & 0.197 \\
\hline 25 & -0.031 & -0.049 & 29.831 & 0.231 \\
\hline 26 & -0.122 & -0.032 & 32.564 & 0.175 \\
\hline 27 & -0.102 & -0.120 & 34.505 & 0.152 \\
\hline 28 & -0.050 & -0.060 & 34.969 & 0.171 \\
\hline 29 & -0.006 & -0.039 & 34.975 & 0.205 \\
\hline 30 & 0.031 & 0.030 & 35.157 & 0.237 \\
\hline 31 & -0.051 & -0.026 & 35.652 & 0.259 \\
\hline 32 & -0.075 & -0.034 & 36.747 & 0.258 \\
\hline 33 & -0.058 & -0.068 & 37.408 & 0.274 \\
\hline 34 & -0.074 & -0.039 & 38.498 & 0.273 \\
\hline 35 & 0.026 & -0.020 & 38.635 & 0.309 \\
\hline & & & & \\
\hline
\end{tabular}

It is seen that $\mathrm{F}$ statistics value taking place in Table 7 is higher than p-probability values taking place in Table 8 . In this case, it is seen that there is no problem with autocorrelation for Model 1.

After White Test made, in order to test whether or not there is cointegration between variables, bound test was made. The results of bound test made for Model 1 are shown in Table 9.
Table 9: The Results of Bound Test for Model 1

\begin{tabular}{|l|l|l|l|}
\hline AIC Lagging Length & $(3,0,0)$ \\
\hline F Statistics Value & 7.48 \\
\hline Table Critical Values & \multicolumn{3}{l}{} \\
\hline Significance Levels & $\% 1$ & $\% 5$ & $\% 10$ \\
\hline Lower Critical Value I(0) & 4.13 & 3.1 & 2.63 \\
\hline Upper Critical Value I(1) & 5.00 & 3.87 & 3.35 \\
\hline
\end{tabular}

When regarded to $\mathrm{F}$ statistics value taking place in the table, due to the fact that F statistics value that is 7.48 is higher than 3.35 , upper limit, at $10 \%$ significance level, it is seen that there is a cointegration relationship between the variables. That is, according to the results of bound test, there is a long-term relationship between the variable CDS and foreign direct investments.

When regarded to the significance of long-term relationship that is existent between the variables, from long term results taking place in Table 10, it can be concluded that this longterm relationship is not significant.

Table 10: Long Term Results for Model 1

\begin{tabular}{|l|l|l|}
\hline Variables & Coefficient Values & T Statistics Value \\
\hline LOG(CDS) & -0.10 & $-0.27(0.79)$ \\
\hline KRIZ & & $0.15(0.88)$ \\
& & \\
\hline
\end{tabular}

As will also be seen from the table, probability value of CDS variable, whose logarithm was taken, is 0.75 and this value is high at the significance level of $10 \%$.

For Model 1, the results of Cusum test made on the name of testing whether or not long-term relationships are in a stable structure are shown in Graph 1. 
Graph 1: The Results of Cusum Test for Model 1.

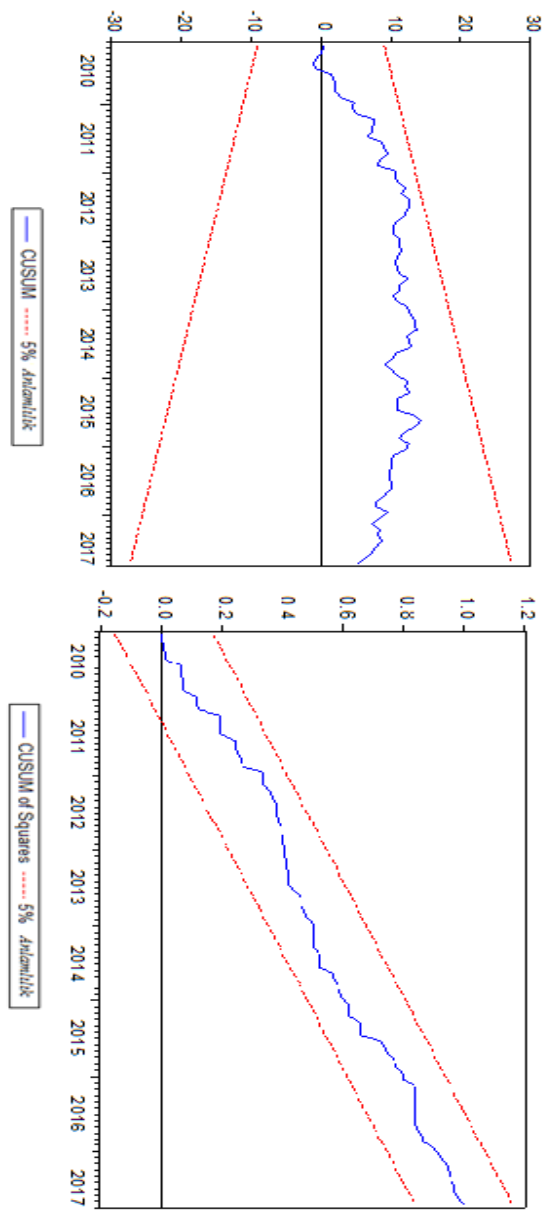

According to the results of Cusum Test, for Model 1, long term relationships of the variables are seen in a stable structure.

Although long term relationships between the variable CDS and foreign direct investments are not significant, for studying the possible short-term relationships between the same variables, error correction model was formed. The results regarding error correction model are shown in Table 11.

Table 11: Error Correction Model for Model 1 and Short-Term Results

\begin{tabular}{|l|l|l|}
\hline Variables & $\begin{array}{l}\text { Coefficient } \\
\text { Values }\end{array}$ & $\begin{array}{l}\text { T Statistics } \\
\text { Values }\end{array}$ \\
\hline
\end{tabular}

1. The values in parentheses taking place in the table express probability values.

\begin{tabular}{|l|l|l|}
\hline $\begin{array}{l}\text { DLOGYABANCI } \\
(-\mathbf{1})\end{array}$ & -0.20 & $-1.95(0.05)$ \\
\hline $\begin{array}{l}\text { DLOGYABANCI } \\
(-2)\end{array}$ & -0.23 & $-2.92(0.00)$ \\
\hline DLOGCDS & 0.32 & $0.56(0.57)$ \\
\hline DKRiZ & 0.30 & $0.51(0.61)$ \\
\hline HATA & 0.66 & $5.48(0.00)$ \\
\hline
\end{tabular}

When regarded to the results in the Table, it is concluded that short term relationships between the variable CDS and foreign investments are not also significant. In spite of this, the coefficient of error term that is 0.66 expresses that short-term unbalances in the model are removed at the rate of $66 \%$ at the significance level of $1^{\wedge} \%$ in the long term.

\subsubsection{Model 2: The Relationship of CDS with Portfolio Investments}

The results of ARDL application for Model 2 are shown in Table 12. In the table, in addition to coefficient values of the variables in the table, t-statistics and probability values, definitional test results take place.

Table 12: For Model 2, ARDL $(1,1,0)$ Results $^{1}$

\begin{tabular}{|l|l|l|l|}
\hline AIC Lagging Length & \multicolumn{1}{l|}{$(1,1,0)$} \\
\hline F Statistic Value & \multicolumn{2}{l|}{} \\
\hline Table Critical Values & $\% 15$ & $\% 5$ & $\% 10$ \\
\hline Significance Level & \multicolumn{5}{|l|}{} \\
\hline Lower Critical Value I(0) & 4.13 & 3.1 & 2.63 \\
\hline Upper Critical Value I(1) & 5.00 & 3.87 & 3.35 \\
\hline Results of Definional Test & & & \\
\hline
\end{tabular}




\begin{tabular}{|l|l|}
\hline \multicolumn{1}{|c|}{$\boldsymbol{R}^{2}$} & 0.48 \\
\hline Adjusted $\boldsymbol{R}^{2}$ & 0.46 \\
\hline Ramsey-Reset Test & \\
\hline Jague Bera Normality Test & $1.76(0.08)$ \\
& \\
\hline Durbin Watson Test & $1.99(0.37)$ \\
& \\
\hline F Statistics Value & 2.02 \\
& \\
\hline
\end{tabular}

When regarded to the results of bound test for Model 2, it is seen that $\mathrm{F}$ statistic value is 28.45 . Since this value is bigger than 3.35 that is a critical value, it is concluded that there is a co-integration relationship between the variables. According to this, what is under consideration is that there is a long term relationship between the variables.

When the values of $\mathrm{R}^{2}$, obtained in bound test, and adjusted $\mathrm{R}^{2}$ are regarded to, it is seen that there are 0.48 and 0.46 , respectively. These values mean that the power of dependent variable to account for independent variable is not so high. F value, obtained in bound test, is 33.46 , it expresses that model is wholly significant. Durbin Watson Test having the value of 1.96 indicates that there is no problem with autocorrelation; RamseyReset Test having the value of 1.76 , specification; and Jague Bera Test having the value of 1.99 , normal distribution.

After bound test, made for Model 2, about long-term relationship between the variables, it can be looked at Table 14

Table 14: Long Term Results for Model 2

\begin{tabular}{|l|l|l|}
\hline Variables & Coefficient Values & T Statistics Value \\
\hline CDS & -8.26 & $-2.80(0.00)$ \\
\hline KRIZ & 351.42 & $0.88(0.38)$ \\
& & \\
\hline
\end{tabular}

When regarded to long term relationship related to Model 2, it is seen that there is significant relationships between credit swaps and portfolio investments for Turkey. That coefficient value of CDS variables means that a fall in CDS premium increases portfolio investments. Thus, as also expressed in the first section of the study, that CDS premium decreases means that the risk regarding the country of interest decreases, which is a case that will promote the inflow of portfolio investments to the country.

In the model of interest, in order to study whether or not long term relationships are stable, Cusum and Cusum Q tests are made. Cusum Q test is a more sensitive one compared to Cusum test. According to these tests, if test statistics is in the limits at $5 \%$ significance level, it is expressed that there is no structural break in the model. Graphic 2 shows the results of structural break for Model 2.

Graph 2: Results of Structural Break for Model 2

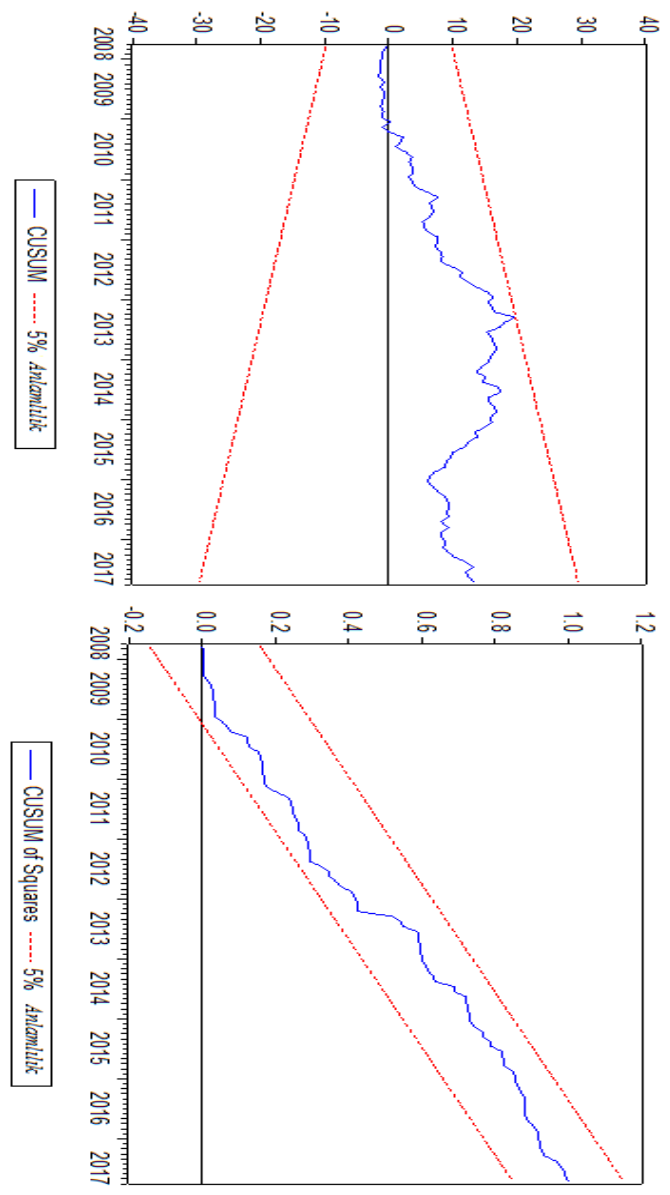


In order to identify whether or not there is short term relationship for Model 2, error correction model was formed. The results regarding error correction model formed are shown in Table 15.

Table 15: Error Correction Model for Model 2 and Short-Term Results

\begin{tabular}{|l|l|l|}
\hline Variables & Coefficient Values & T Statistics Values \\
\hline D(CDS) & -30.13 & $-6.09(0.00)$ \\
\hline D(KRIZ) & -181.12 & $-0.13(0.89)$ \\
\hline HATA & -0.81 & $-10.74(0.00)$ \\
\hline
\end{tabular}

When regarded to the results taking place in the table, in short term, it is seen that there is a significant relationship between the variable CDS and portfolio investments. Beside this, that error correction coefficient is significant at the significance level of $1 \%$ reveals the conclusion that unbalances taking place in the model are eliminated at the rate of $81 \%$.

In the context of the results obtained by error correction model, when regarded to short term effect of the variables, it reveals the conclusion that $1 \%$ increase in CDS premium reduced portfolio investments by 30.13

\section{Conclusion and Suggestions}

In this study, the relationship of CDSs with direct foreign investments and portfolio investments was examined for Turkey. In examination of this relationship, 5-year CDS premiums and foreign direct investments and portfolio investments on Turkey were basically used. The study of interest were carried out by using Eviews program for the period 2005:1-2017:9. As a method, ARDL (Autoregressive Distributed Lag Model) was used.

In the study, in order to study whether or not the variables have unit root i.e. stationarity of the variables, Augmented Dickey Fuller (ADF), Phillips Perron (PP) and Zivot Andrews (ZA) tests were used.

Among the tests made, in ADF test, the presence of unit root was tested in three models as "with constant", "with constant - with trend" and "without constant -without trend". According to the test results, it is seen that while CDS variable has unit root in "without constant -without trend" models and "with constant with trend" models, the variable YABANCI has unit root in "without constant-without trend" model. The study results of the variable PORTFOY turned out stationary for three models. In the study of interest, due to unit roots that are present in the variables CDS and YABANCI, the first difference of three variables was also taken and it was seen that they became stationary at the first level.

According to PP test, it was concluded that while the variable CDS had unit root in "without constant - without trend", the variables YABANCI and PORTFOY variables were stationary at the level. When their first differences were taken, it was seen that three variables were also stationary in three models.

According to the results of ZA test, it was seen that there were structural breaks in three variables as well. In the "with constant" "with trend" and "with constant -with trend" models, formed for this test, when regarded to the breaks of the variables, it was concluded that for CDS variable, there were structural breaks in the periods of May 2013, November 2008, and April 2009; and for the variable PORTFOY, in the periods of May 2013, November 2012 and February 2015. When regarded to structural breaks for the variable YABANCI, it was concluded that there were structural breaks in the periods of August 2008 and December 2009. For "with constant - with trend" model, since there is no full rank, break could not be observed.

Later, due to structural breaks, Mortgage Crisis in the period that is subject of analysis (2005/01-2017/09), and 2009 European Debt Crisis, immediately experienced following this crisis, the variable KRIZ was included in the analysis as dummy variable and analysis was continued by ARDL test.

In this study, carried out by applying ARDL method, two models were established. In the first model, long and short-term relationships between the variable CDS and foreign direct investments were studied; in the second model, the long- and short-term relationships between the variable CDS and portfolio investments. 
According to the findings of the first model, for the period 2005/01-2017/09, it was obtained the conclusion that the relationships, either long or short term, between CDS premium of Turkey and foreign investments, made on Turkey in the same period, were not significant. When considered that CDS premium is an indicator of risk perception, this result overlaps with the conclusion by Bevan and Estrin (2004) that the effect of country risk on foreign direct investments is insignificant.

According to the findings of the second model, for the period that is the subject of the analysis, it was concluded that there was a significant relationship between CDS premium of Turkey and portfolio investments on Turkey in both long and short term. This conclusion expressing the significant relationships between CDS premium and portfolio investments overlap with the conclusion by Norden and Weber (2004) that CDS markets made leadership to bond markets, when country bonds are assessed in the framework of portfolio investments. On the other hand, in the study by Özkaplan (2011), carried out by means of IMKB 100 , Dow Jones Index, and the other financial indices, this overlaps with the conclusion that CDSs played a leadership role, when considered that local investors as well as foreign investors take place.

Although CDSs are known as instruments affecting investment decisions, this study proves the relationship of CDS premium with portfolio investments, mostly accepted as hot money flow.

In the light of the results of this empirical analysis, although CDS premium processed in financial markets is accepted as an indicator of risk premium, it can be in fact said that it is an financial instrument mostly used with speculative purpose. When the relationship of CDS premium with the grades assigned by credit rating agencies is considered, it is seen that CDS premium does not have any relationship with foreign direct investments in specific to Turkey; in spite of this, that it has either long or short term relationship with portfolio investments and, as theoretically accepted, that risk perception of an increase in risk premium is high and, in such a case, that foreign investor to make portfolio investment backs down from investment decision. That is, a rise in CDS premium reduces portfolio investments, in contrast to this, i.e. decrease in CDS premium rises portfolio investments.
Although CDS premium, accepted as a risk indicator about whether or not countries will fulfill their liabilities, is not the only determinative element in the decisions of foreign investors regarding portfolio investments, it can be said that it is an important variable. From this aspect, developing new measurement techniques in the way that it can more clearly reveal the possible country risks related to not being able to fulfill liability can enable foreign investors considering portfolio investment to make more healthily decisions.

For Turkey, when considered that the conclusion that CDSs do not have significant relationships with foreign investments, developing an index similar to foreign direct capital reliability index for shorter terms instead of long term can allow for making more sensitive analyses regarding foreign direct investments. Setting out from this index, forming derivative indices for the subjects such as sectors, provinces, and investment prices can make easier.

\section{References}

5. Bevan, Alan A.; Estrin Saul. The Determinants of Foreign Direct Investment into European Transition Economies, Journal of Comparative Economics, 32(4): 775-787, 2004.

6. Castaneda, Andres; Vargas, Juan F. Sovereign Risk and Armed Conflict: An Event-Study For Colombia Defence And Peace Economics 23:2 p.185-201, 2012

7. Cho, Dongchul; Rhee, Changyong Effects of Quantitative Easing on Asia: Capital Flows and Financial Markets Singapore Economic Review Vol:59 (3) p.1-23, 2014

8. Coronado, Maria; Corzo, Teresa; Lazcano, Laura. A Case for Europe: The Relationship Between Sovereign CDS And Stock Indexes Frontiers Finance \& Economics. Vol: 9 Issue: 2 32-63, 2012.

9. Da Costa Filho, Adonias Evaristo What Drives Long Term Real Interest Rates In Brazil Brazilian Business Review Vol.14 (6) p.624-635, 2017

10. Esen, Ethem; Yıldırım Selim; Kostakoğlu Fatih Felstein -Horioka Hipotezinin Türkiye Ekonomisi İçin Sinanması: ARDL Modeli Uyglaması, Eskişehir 
Osmangazi

11. Kim, Bong-Han; Kim, Hyeongwoo; Lee, Bong-Soo Spillover Effects Of The U.S. Financial Crisis On Financial Markets In Emerging Asia Countries International Review Of Economics And Finance Vol.39 p.192-210, 2015

12. Kocsis, Zalan; Monostori, Zoltan The Role Of Country-Specific Fundamentals In Sovereign CDS Spreads: Eastern European Experiences Emerging Markets Review 27 p.140-168, 2016

13. Koy, Ayben. Kredi Temerrüt Swaplarl ve Tahvil Primleri Üzerine Ampirik Bir Çalışma International Review Of Economics and Management Vol: No:2 s.63-79 2014 http://dergipark.gov.tr/download/article-file/92555

Erişim Tarihi: 24.04.2017

14. Koziol, Christian; Koziol, Philipp; Schön, Thomas Do Correlated Defaults Matter for CDS Premia? An Empirical Analysis Review Of Derivatives Research Vol:18 (3) p.191-224, 2015

15. Kurt, Ünzüle Türkiye'de Döviz Kurlarının Açıklanmasında Varlık Piyasalarının Rolü: Portföy Denge Modeli Üzerine Ampirik Analiz Çanakkale Onsekiz Mart Üniversitesi Sosyal Bilimler Enstitüsü Doktora Tezi Çanakkale 2016.

16. Liu, Yang; Morley, Bruce Sovereign Credit Default Swaps And The Macroeconomy Applied Economic Letters Vol.19 (2) p.129-132, 2012

17. Marzano, Michele; Dunn, Gary; Constantinou, Nick the Relationship Between Credit default Spreads And Equity Price Journal of Risk Vol:17 No:1 3-28, 2014.

18. Nordal, Kjell. B. Country Risk, Country Risk Indices and Valuation of FDI: A Real Options Approach. Emerging Markets Review, 2, 197-217. 2001.

19. Norden, Lars; Weber, Martin Informational Efficiency Of Credit Default Swap And Stock Markets: The Impact Of Credit Rating Announcements Journal Of Banking \& Finance Vol:28 (11) p.2813-2843, 2004

20. Özkaplan, Dilek. Türkiye Kredi Temerrüt Takaslarl ve Finansal Göstergelerle İlişkisi İstanbul Bilgi Üniversitesi Sosyal Bilimler Enstitüsü Bankacılık ve Finans Programı Yüksek Lisans Tezi İstanbul, 2011.
21. Pereira Da Silva, Paulo Did Investor Seeking Short Exposure Move to The CDS Market After The 2011 Short-Sale Bans in Europan Financial Stock? Finance a Uver-Czech Journal Of Economics And Finance 66 (4) p.322-353, 2016

22. Stolbov, Mikhail. The Causal Linkages Between Sovereign CDS Prices for the BRICS and Major European Economies. Economics, vol. 8, no. 1, 27 144 June 2014

23. Topal, Mehmet Hanefi; Gül, Özlem. S. Ekonomik Risk Ile Doğrudan Yabancı Sermaye Yatırımlarl Arasındaki Illişki: Türkiye Örneği GümüshaneUniversity Electronic Journal Of The Institute Of Social Science / Gümüshane Üniversitesi Sosyal Bilimler Enstitüsü Elektronik Dergisi, 7(15), 229-247. 2016.

24. Tuna, Kadir. ; Öner, Selma ; ÖNER, Hakan. 2008 Küresel Kriz Döneminde Türkiye Ille Gelişmekte Olan Ülkeler Arasinda Krizin Yayılma Etkisinin Incelenmesine Yönelik Bir Çalışma Cumhuriyet Üniversitesi İktisadi Ve İdari Bilimler Fakültesi Dergisi, 15(1), 21. 2014 